\title{
Covid-19 Infection and the Host Genetic Predisposition: Does it Exist?
}

\author{
Anna VAŠKK ${ }^{1}$ \\ ${ }^{1}$ Department of Pathological Physiology, Faculty of Medicine, Masaryk University, Brno, Czech \\ Republic
}

Received May 19, 2020

Accepted July 7, 2020

\section{Summary}

Knowledge of genomic interindividual variability could help us to explain why different manifestation of clinical severity of Covid-19 infection as well as modified pharmacogenetic relations can be expected during this pandemic condition.
\end{abstract}

\section{Key words}

ACE2 polymorphisms - COVID 19 - Cardiovascular disease • Diabetes mellitus $\bullet$ Hyperlipoproteinemia $\bullet$ Pharmacogenetics

\section{Corresponding author}

A. Vašků, Department of Pathological Physiology, Faculty of Medicine, Masaryk University, Kamenice 5, 62500 Brno, Czech Republic. E-mail: avasku@med.muni.cz

Trying to understand clinical aspects of coronavirus infection, not only pure immunological mechanisms must be considered. The novel coronavirus uses the same receptor, angiotensin-converting enzyme 2 (ACE2) as that for SARS-CoV (Guo et al. 2020).

Three major functions of ACE2 have been described so far. First, ACE2 emerges as a potent negative regulator of the renin-angiotensin-aldosterone system (RAS), counterbalancing the multiple functions of ACE. By targeting angiotensin II, ACE2 exhibits a protective role in the cardiovascular system and many other organs (Kim et al. 2010). Second, ACE2 has been identified as an essential receptor for the severe acute respiratory syndrome (SARS) coronavirus, which causes severe acute lung failure. Downregulation of ACE2 strongly contributes to the pathogenesis of severe lung failure. Third, both ACE2 and its homologue collectrin can associate with amino acid transporters and play an essential role in the absorption of amino acids in the kidney and gut (Kuba et al. 2005, Kuba et al. 2010). In the context of critical illness, the regulation of the classic/nonclassic RAS balance plays a unique role in the response to vasodilatory shock and acute respiratory distress syndrome (ARDS) (Bitker and Burrell 2019).

As mentioned, the angiotensin-converting enzyme 2 (ACE2) was identified the functional receptor for SARS-CoV in human tissues (Hamming et al. 2004). ACE2 protein was found to be is expressed on lung alveolar epithelial cells and enterocytes of the small intestine, i.e. cells in contact with the external environment. ACE2 was present in arterial and venous endothelial cells and arterial smooth muscle cells in many organs (Hamming et al. 2004). The type I and type II pneumocytes were found to by markedly positive for ACE2; on the contrary, bronchial epithelial cells show only weak staining (Hamming et al. 2004).

Therefore, during clinical manifestation of infection, main regulatory physiological mechanisms of cardiovascular and other organ systems including lungs, kidneys, brain etc. can be modified. Due to Covid-19, previously defined physiological equilibrium between classic (ACE) and non-classic arms (ACE2) of the RAS can be shifted (Boehm and Nabel 2002, Crackower et al. 2002). It is known that renal $\mathrm{ACE} / \mathrm{ACE} 2$ ratio has a significant impact on a variety of diseases including diabetes and hypertension (Mizuiri and Ohashi 2015).

The elderly and people with underlying disease (hypertension, diabetes mellitus, CHOPN, cardiovascular diseases) seem to be more susceptible to Covid-19 and tend to develop into critical conditions. The disease tends to progress faster in elderly people, with the median number of days from the occurrence of the first symptoms to death shorter among people aged 65 years 
or more. Complications included acute respiratory distress syndrome (ARDS), arrhythmia, shock, acute kidney injury, acute cardiac injury, liver dysfunction and secondary infection. The poor clinical outcome was related to disease severity (Guo et al. 2020).

On the other hand, we can observe also younger persons without another disease condition, which died to new coronavirus infection. Why? This question leads us to potential genetic background association with individual variability in the infection response. The first possibility could be analysis of genes coding for ACE and/or ACE2.

The ancestral D allele of I/D angiotensinconverting enzyme (ACE) gene polymorphism was selected as a candidate to confirm the 'thrifty genotype' hypothesis in the framework of evolutionary ecology. The $\mathrm{D}$ allele of ACE gene is not only plastic in response to its environmental circumstance (temperature, humidity) but also presents a striking geographic distribution showing the evidence of 'signatures of selection' by climate factors ( $\mathrm{Li}$ et al. 2011). In 1999, our group published how interaction between polymorphism I/D ACE and ABO blood group system could significantly modify mean values of blood pressure and a phase shift of $24 \mathrm{~h} \mathrm{BP}$ periods corrected for sex and BMI in Czech population (Vašků et al. 1999).

Later, we prove a significant association of ACE2 gene polymorphisms (rs4646156 and rs4646174) with central pulse pressure (PP) measured coronarographically in Czech cardiovascular patients (Vašků et al. 2013). The values of PP were higher in women; significant differences among five genotypes in the population (X-linked heredity of ACE2) were distinguishable which could be of great importance in severe clinically ill patients with Covid-19 infection. We attempted testing ACE2 genotypes as possible independent predictors of central PP using multivariate analysis. The most suitable model included brachial PP, age, ACE2 rs4646174 genotypes and the number of affected arteries (as indicator of cardiovascular disease severity).

In the study, a significant association of genotypes of ACE2 rs4646156 and rs4949174 polymorphisms with body height, weight (but not with body mass index) and with creatinine plasma levels were found. Also, several clinical states have been associated with central pulse pressure (genetically co-determined by ACE2 gene) in these patients indicated to coronarography: hypertension $(\mathrm{P}=0.01$, Table 1), diabetes mellitus $(\mathrm{P}=0.002)$, combination of hypertension and diabetes mellitus $(\mathrm{P}=0.006$, Table 2$)$ and even combination of hypertension, diabetes mellitus and hyperlipoproteinemia $(\mathrm{P}=0.02)$ (unpublished data, data set to publication Vasku et al. 2013). In all these conditions, central pulse pressure was significantly higher in persons with these diseases and/or their combinations. In Chinese epidemiological study, in men, SNP rs4646174 of the ACE2 gene was significantly associated with systolic BP (SBP), DBP, and mean arterial pressure (MAP) responses to potassium supplementation (Zhao et al. 2010). But, Chinese population minor allele frequency seems to be significantly lower $(\mathrm{MAF}=0.038)$ compared to substantially higher frequency observed in our group of patients $(\mathrm{MAF}=0.334)$ which could be of functional importance. Other studies associated different ACE2 polymorphisms with cardiovascular, diabetic and/or respiratory phenotypes (Lieb et al. 2005, Patel et al. 2012, Pan et al. 2018, Liu et al. 2018, Chiu al. 2004), but the results are often inconsistent.

Table 1. Pulse pressure in aorta (PP_ao) in hypertensive and non-hypertensive patients.

\begin{tabular}{lccccc}
\hline Hypertension & $\begin{array}{c}\text { PP_ao } \\
\text { N }\end{array}$ & $\begin{array}{c}\text { PP_ao }[\mathbf{m m} \mathbf{H g}] \\
\text { Median }\end{array}$ & $\begin{array}{c}\text { PP_ao }[\mathbf{m m} \mathbf{H g}] \\
\text { Minimum }\end{array}$ & $\begin{array}{c}\text { PP_ao }[\mathbf{m m} \mathbf{H g}] \\
\text { Maximum }\end{array}$ & P-value \\
\hline No & 78 & 63 & 0 & 114 & 0.01 \\
Yes & 229 & 69 & 0 & 123 & \\
All Groups & 307 & 68 & 0 & 123 \\
\hline
\end{tabular}

Table 2. Pulse pressure in aorta (PP_ao) in patients with both hypertension and diabetes.

\begin{tabular}{lccccc}
\hline $\begin{array}{l}\text { Hypertension }+ \\
\text { diabetes mellitus }\end{array}$ & $\begin{array}{c}\text { PP_ao } \\
\mathbf{N}\end{array}$ & $\begin{array}{c}\text { PP_ao }[\mathbf{m m} \mathbf{H g}] \\
\text { Median }\end{array}$ & $\begin{array}{c}\text { PP_ao }[\mathbf{m m} \mathbf{H g}] \\
\text { Minimum }\end{array}$ & $\begin{array}{c}\text { PP_ao }[\mathbf{m m} \mathbf{H g}] \\
\text { Maximum }\end{array}$ & P-value \\
\hline No & 240 & 67 & 0 & 118 & 0.006 \\
Yes & 67 & 71 & 34 & 123 & 123 \\
All Groups & 307 & 68 & 0 & & \\
\hline
\end{tabular}


Due to linkage disequilibrium in genome, an important association for the combination of I/D $A C E$ DD genotype with G8790A ACE2 GG genotype (DD/GG) on Brazilian female subjects was found, that conferred a significant 7-times increased risk of hypertension compared to individuals carrying the II/GG genotype in Brazilian population (Pinheiro et al. 2019).

Due to COVID-19 pandemic condition, role of therapeutical renin-angiotensin system inhibition in patients with COVID-19 started to be discussed (Aleksova et al. 2020). According to our previous results, inhibitors of ACE were given almost twice more frequently to cardiac men with G0 genotype in ACE2 rs4646174 polymorphisms compared to those with C0 genotype $(\mathrm{P}=0.03, \quad \mathrm{OR}=1.88,95 \%$ CI 1.03-3.81, sensitivity 0.75 , specificity 0.40 ). The cardiac men with A0 genotype in ACE2 rs4646156 polymorphisms were almost three times more frequently treated by AT1R blockers compared to those with $\mathrm{T} 0$ genotype $(\mathrm{P}=0.04$, OR 2.93, $95 \%$ CI 1.03-8.33, sensitivity 0.56 , specificity $0.70)$. No similar pharmacogenetic association were observed in women. Of course, treatment decision was done by clinicians, without information about ACE2 genotypes (unpublished results, data set to publication Vašků et al. 2013).

All these results support the importance of knowledge of genetic (better genomic) interindividual variability for prediction of population susceptibility to Covid-19. Due to different population frequencies of susceptibility gene alleles related to adaptation of these populations, different manifestation of clinical severity of Covid-19 infection as well as stratification of expected pharmacogenetic effects can be expected in worldwide population.

\section{Conflict of Interest}

There is no conflict of interest.

\section{Acknowledgements}

This study was supported by a grant from the Internal Grant Agency of the Ministry of Health of the Czech Republic /GA NS/10206-3/2009.

\section{References}

ALEKSOVA A, FERRO F, GAGNO G, CAPPELLETTO C, SANTON D, ROSSI M, IPPOLITO G, ZUMLA A, BELTRAMI AP, SINAGRA G. COVID-19 and renin-angiotensin system inhibition: role of angiotensin converting enzyme 2 (ACE2) - is there any scientific evidence for controversy? J Intern Med, 2020. https://doi.org/10.1111/joim.13101

BITKER L, BURRELL LM: Classic and nonclassic renin-angiotensin systems in the critically ill. Crit Care Clin 35 : 213-227, 2019. https://doi.org/10.1016/j.ccc.2018.11.002

BOEHM M, NABEL EG: Angiotensin-converting enzyme 2 - a new cardiac regulator. New Engl J Med 347 : 1795-1797, 2002. https://doi.org/10.1056/nejmcibr022472

CHIU RWK, TANG NLS, HUI DSC, CHUNG GTY, CHIM SSC, CHAN KCA, SUNG Y, CHAN LYS, TONG Y, LEE W, CHAN PKS, DENNIS LO YM: ACE2 gene polymorphisms do not affect outcome of severe acute respiratory syndrome. Clin Chem 50: 1683-1689, 2004. https://doi.org/10.1373/clinchem.2004.035436

CRACKOWER MA, SARAO R, OUDIT GY: Angiotensin-converting enzyme 2 is an essential regulator of heart function. Nature 417: 822-828, 2002. https://doi.org/10.1038/nature00786

GUO YR, CAO QD, HONG ZS, TAN YY, CHEN SD, JIN HJ, TAN KS, WANG DY, YAN Y: The origin, transmission and clinical therapies on coronavirus disease 2019 (COVID-19) outbreak - an update on the status. Mil Med Res 7: 1-11, 2020. https://doi.org/10.1186/s40779-020-00240-0

HAMMING I, TIMENS W, BULTHUIS ML, LELY AT, NAVIS G, VAN GOOR H: Tissue distribution of ACE2 protein, the functional receptor for SARS coronavirus. A first step in understanding SARS pathogenesis. J Pathol 203: 631-637, 2004. https://doi.org/10.1002/path.1570

KIM MA, YANG D, KIDA K: Effects of ACE2 inhibition in the post-myocardial infarction heart. J Card Fail 16: 777-785, 2010. https://doi.org/10.1016/i.cardfail.2010.04.002

KUBA K, IMAI Y, OHTO-NAKANISHI T: Trilogy of ACE2: A peptidase in the renin-angiotensin system, a SARS receptor, and a partner for amino acid transporters. Pharmacol Ther 128: 119-128, 2010. https://doi.org/10.1016/j.pharmthera.2010.06.003 
KUBA K, IMAI Y, RAO S: A crucial role of angiotensin converting enzyme 2 (ACE2) in SARS coronavirus-induced lung injury. Nature Med 11: 875-879, 2005. https://doi.org/10.1038/nm1267

LI X, SUN X, JIN L, XUE F: Worldwide spatial genetic structure of angiotensin-converting enzyme gene: a new evolutionary ecological evidence for the thrifty genotype hypothesis. Eur J Hum Genet 19: 1002-1008, 2011. https://doi.org/10.1038/ejhg.2011.66

LIEB W, GRAF J, GÖTZ A, KÖNIG IR, MAYER B, FISCHER M, STRITZKE J, HENGSTENBERG C, HOLMER SR, DÖRING A, LÖWEL H, SCHUNKERT H, ERDMANN J: Association of angiotensin-converting enzyme 2 (ACE2) gene polymorphisms with parameters of left ventricular hypertrophy in men. Results of the MONICA Augsburg echocardiographic substudy. J Mol Med (Berl) 84: 88-96, 2006. https://doi.org/10.1007/s00109-005-0718-5

LIU C, LI Y, GUAN T, LAI Y, SHEN Y, ZEYAWEIDING A, ZHAO H, LI F, MAIMAITI T: ACE2 polymorphisms associated with cardiovascular risk in Uygurs with type 2 diabetes mellitus. Cardiovasc Diabetol 17: 127-138, 2018. https://doi.org/10.1186/s12933-018-0771-3

MIZUIRI S, OHASHI Y: ACE and ACE2 in kidney disease. World J Nephrol 4: 74-82, 2015. https://doi.org/10.5527/wjn.v4.i1.74

PAN Y, WANG T, LI Y, GUAN T, LAI Y, SHEN Y, ZEYAWEIDING A, MAIMATI T, ZHAO H, LIU C: Association of ACE2 polymorphisms with susceptibility to essential hypertension and dyslipidemia in Xinjiang, China. Lipids Health Dis 17: 241-250, 2018. https://doi.org/10.1186/s12944-018-0890-6

PATEL SK, WAI B, ORD M, MACISAAC RJ, GRANT S, VELKOSKA E, PANAGIOTOPOULOS S, JERUMS G, SRISTASAVA PM, BURRELL LM: Association of ACE2 genetic variants with blood pressure, left ventricular mass, and cardiac function in Caucasians with type 2 diabetes. Am J Hypertens 25: 216-222, 2012. https://doi.org/10.1038/ajh.2011.188

PINHEIRO DS, SANTOS RS, JARDIM PCBV, SILVA EG, REIS AAS, PEDRINO GR, ULHOA CJ: The combination of ACE I/D and ACE2 G8790A polymorphisms revels susceptibility to hypertension: A genetic association study in Brazilian patients. PLoS One 14: 1-15, 2019. https://doi.org/10.1371/journal.pone.0221248

VAŠKŮ A, BIENERTOVÁ-VAŠKU゚ J, PAŘENICA J, GOLDBERGOVÁ MP, LIPKOVÁ J, ZLÁMAL F, KALA P, SPINAR J: ACE2 gene polymorphisms and invasively measured central pulse pressure in cardiac patients indicated for coronarography. J Renin Angiotensin Aldosterone Syst 14: 220-226, 2013. https://doi.org/10.1177/1470320312460291

VAŠKŮ A, SOUCEK M, HÁJEK D, HOLLÁ L, ZNOJIL V, VÁCHA J: Association analysis of 24-h blood pressure records with I/D ACE gene polymorphism and ABO blood group system. Physiol Res 48: 99-104, 1999.

ZHAO Q, GU D, KELLY TN, HIXSON JE, RAO DC, JAQUISH CE, CHEN J, HUANG J, CHEN CS, GU CC, WHELTON PK, HE J: Association of genetic variants in the apelin-APJ system and ACE2 with blood pressure responses to potassium supplementation: the GenSalt study. Am J Hypertens 23: 606-613, 2010. https://doi.org/10.1038/ajh.2010.36 